section of the Organization. Lists of professional staff, published scientific papers and financial details are excluded and are given in the annual report.

\section{Research Grants in Science and Medicine in Canada}

THE report on University Support, 1960-61 (Pp. 123. N.R.C. No. 6390. Ottawa: National Research Council and Medical Research Council, 1961. 50 cents), issued by the National Research Council and the Medical Research Council of Canada, records support totalling $8,169,564$ dollars from the National Research Council and 2,304,467 dollars from the Medical Research Council. Of the former figure, $7,169,402$ dollars represent direct support by way of scholarships in science and engineering $(738,467)$, fellowships in science and engineering $(396,758)$ and grants in aid of research through the Assisted Researches Committee $(4,267,195)$, Prairie Regional Committee (232,458), Atomic Energy Control Board $(650,000)$ or General Research grants $(492,000)$, and $1,000,162$ dollars indirect support, including 285,589 dollars for publication costs of research journals and 227,334 dollars for the administration of the programme. The latter includes 189,326 dollars for fellowships, 204,191 dollars for associateships and $1,899,809$ dollars for grants in aid of research. The totals represent increases of 1.11 million dollars over 1959-60 and 7 million dollars over 1956-57. Besides listing the membership of the Councils and their officers and committees, the report lists the recipients of fellowships, bursaries and scholarships for the period 1960-61 and the subjects of research grants.

\section{The Wildfowl Trust}

THE Wildfowl Trust has again prepared an annual report which is a model of presentation (The Twelfth Annual Report of the Wildfowl Trust, 1959-1960. By Hugh Boyd and Peter Scott. Pp. $185+24$ plates. Slimbridge: The Wildfowl Trust, 1961. 17s. 6d. net). Practical administrative matters are described clearly and briefly, scientific topics are many and varied, and there are the usual high-quality photographs and line drawings which make the reading of the report an event to be anticipated rather than a duty to be overcome. Unfortunately, the twelfth year of the life of the Trust has seen a drop in the number of visitors to Slimbridge and Peakirk, and it is to be hoped that the decline is only temporary. Probably the most interesting and disturbing scientific article is one by $J$. M. and J. G. Harrison, who have collected evidence to show that radioactive contamination in birds is beginning to increaso. While risks to wildfowl are but a tiny facet of the bigger problem of radioactive contamination, wildfowl may be particularly susceptible, especially those breeding in the far North, where the hazards from radioactive fall-out may be at their greatest. The added risks from the disposal of radioactive industrial waste products may again render wildfowl and seabirds more susceptible than other groups of birds.

\section{London and Guildhall Museums}

THE Government and the Corporation of London and the London County Council have agreed in principle to establish one Museum dealing with the history of London. This will involve the amalgamation of the present London and Guildhall Museums and the full approval of each of the governing bodies is assured. The now Museum will be situated in the City of London, probably on a site close to the Roman Wall. Although details have not yet been agreed, it is probable that the governing body will consist of representatives appointed by the Prime Minister, the City Corporation and the London County Council. When the details have been agreed by the authorities, an Act of Parliament will be necessary to implement the scheme.

\section{Rocket Propulsion Thirty Years Ago}

THE science and technology of rockets have advanced from being the hobby of a few apparent cranks to become major consumers of taxpayers' money; even in the universities the type of student who immediately after the War would have sought to accomplish research on the gas turbine, and later would have followed changing fashion and interested himself in nucleonics, now regards rockets as pointing the way to the stars. In spite of the great achievements of the age, however, it is interesting to look back at the pioneer work of another student at the Imperial College of Science and Technology, London. A paper, originally read by $\mathrm{Mr}$. Paul Adorian in 1929, has been reprinted and the proceeds from the sale of these reprints is to be given to the Henry Tizard Memorial Fund. The paper contains little original matter, but it does give a picture of the approach to rocket propulsion more than thirty years ago, and a contemporary point of view of such developments as the Opel rocket cars, designs for jet aircraft curiously modern in style, and a German rocket gun which its open-minded inventor claimed could "shoot London from Berlin, or if you prefer it, shoot Berlin from London". Copies of the reprints are available from Mr. P. Adorian, 21 Denmark Street, London, W.C.2 (price 8s. or 1.25 dollars).

\section{The Cambridge Rheology Club}

A RECENT meeting of the Cambridge Rheology Club was held on September 11 in the form of an exhibition of rheological equipment. Mr. C. H. Rose (Cambridge Instrument Co.) demonstrated the dye dilution curve recorder and described its uses in the investigation of certain defects of the vascular system. Grant Instruments showed notably a low-temperature thermostatically controlled bath (Model RB6P). Miss M. Nicholas (Spillers, Ltd.) demonstrated the cattle cube hardness tester, which may also be used for strength tests on paper and similar materials. She dealt briefly with the statistical evaluation of the results. Dr. N. A. de Bruyne (Techne, Ltd.) discussed an extensive range of rheological instruments, including the gelation timer, capillary viscometer, various temporature control units and the automatic printing viscometer, still in the experimental stage. The next meeting of the Club will be held on November 27 , at 7.45 p.m., when Dr. R. MeKennell (Ferranti, Ltd.) will speak on "Rotation Viscometers and their Application to NonNewtonian Measuremonts", followed by a demonstration of the Ferranti-Shirley viscometer. Further information can be obtained from Mr. H. G. Muller, Spillers, Ltd., Technological Research Station, Station Road, Cambridge.

\section{Tables and Charts for Use in Gas Dynamic Studies}

THE Sandia Corporation has recently issued a very useful bibliography (SCR-299), by D. E. Randall, listing references which provide tabulated or graphical data regarding the atmosphere, gas flows, flow through shock waves, and information on the thermodynamic and transport properties of gases. Included in the list is a new Sandia monograph $(S C R-288)$, by K. L. 